\title{
RELATION OF ELECTROMOTIVE FORCE TO THE CON- CENTRATION OF DEUTERIUM OXIDE IN SATURATED STANDARD CELLS
}

\author{
By Langhorne H. Brickwedde and George W. Vinal
}

\section{ABSTRACT}

Characteristics of saturated cadmium cells, containing small percentages of deuterium oxide $\left(\mathrm{D}_{2} \mathrm{O}\right)$, were described in an earlier paper. The work has since been extended to include various concentrations up to 98 mole percent of $\mathrm{D}_{2} \mathrm{O}$. For each group of the cells, crystals of cadmium sulfate were prepared in equilibrium with the isotopic composition of the respective saturated solutions. At 98 mole percent of $\mathrm{D}_{2} \mathrm{O}$ the electromotive force is 388 microvolts less than that of the control cells containing normal water. The relation between the electromotive force of the cells and the $\mathrm{D}_{2} \mathrm{O}$ content of the water is linear from 0 to 50 percent. Above 50 percent the electromotive force is decreased slightly more. The changes in electromotive force with temperature, hysteresis effects, and internal resistance of the cells were measured. Observations on cells made 4 years ago, as well as those made more recently, justify the conclusion that cells containing $\mathrm{D}_{2} \mathrm{O}$ are as reproducible and constant as the more usual type made with normal water. The difference between the partial molal free energy of $\mathrm{CdSO}_{4}$ in $\mathrm{H}_{2} \mathrm{O}$ and $\mathrm{D}_{2} \mathrm{O}$ solutions is calculated.

\section{CONTENTS}

I. Introduction

II. Experimental procedure _...

1. Preparation of materials _.

2. Construction of the cells

3. Determination of $\mathrm{D}_{2} \mathrm{O}$ content...... 482

4. Electrical measurements _........ 482

III. Experimental results....

1. Electromotive force of the cells

2. Relation of electromotive force to $\mathrm{D}_{2} \mathrm{O}$ content......... 483

3. Temperature coefficient and hysteresis

4. Internal resistance $\ldots . . . \ldots \ldots 6$

5. Constancy of electromotive force

IV. Relative free energy of $\mathrm{CdSO}_{4}$ in $\mathrm{H}_{2} \mathrm{O}$ and $\mathrm{D}_{2} \mathrm{O}$ solutions

$\checkmark$. Conclusion ..... 489

VI. References .

\section{INTRODUCTION}

The effect of small percentages of deuterium oxide $\left(\mathrm{D}_{2} \mathrm{O}\right)$ on the properties of saturated standard cells was reported by the present authors in a previous paper [1]. ${ }^{1}$ This work has now been extended to include the preparation of cells containing $\mathrm{D}_{2} \mathrm{O}$ up to 98 mole percent. Predictions based on the former work have been substantially confirmed by the behavior of cells containing higher percentages.

\footnotetext{
1 Figures in brackets indicate the literature references at the end of this paper.
} 
Practical reasons for continuing the work are based on the desirability of obtaining modified forms of saturated standard cells which are equal, if not superior, to those now in use as standards of electromotive force. The earlier cells and those described in this paper are as reproducible and constant as control cells made with ordinary water, but observations extending over a much longer period of time are needed before conclusions can be drawn about their serviceability as primary standards of electromotive force.

There is considerable theoretical interest also in the effect of $\mathrm{D}_{2} \mathrm{O}$ on the electromotive force of a system which can be measured to a high degree of precision.

In the earlier work 12 saturated cadmium cells containing several different concentrations from 0 to 5 mole percent of $\mathrm{D}_{2} \mathrm{O}$ were constructed. The new group comprises 17 cells in all, and it is divided into 5 subgroups of 3 or more cells each, containing $0,6,49,81$, and 98 mole percent of $\mathrm{D}_{2} \mathrm{O}$, respectively.

Several problems developed in the course of the work. Those relating to solubility of the salt and properties of the solutions will be described in a subsequent paper. Unforeseen conditions of metastability of cadmium sulfate were found, and the transition temperature from $\mathrm{CdSO}_{4} \cdot 8 / 3 \mathrm{H}_{2} \mathrm{O}$ to $\mathrm{CdSO}_{4} \cdot \mathrm{H}_{2} \mathrm{O}$ was fixed by both electromotive force and solubility measurements at about $43^{\circ} \mathrm{C}$, which is $30^{\circ}$ lower than previously reported. The results on cells in a metastable condition have been reported in another paper [2].

\section{EXPERIMENTAL PROCEDURE}

\section{PREPARATION OF MATERIALS}

Some modifications of the usual procedure in making standard cells were required to avoid dilution of the $\mathrm{D}_{2} \mathrm{O}$ solutions by ordinary water and to avoid evaporation. Since each solution was to be saturated with anhydrous cadmium sulfate, it was necessary first to determine the comparative solubility of the salt in ordinary water and in the respective solutions of $\mathrm{D}_{2} \mathrm{O}$. This was done at several temperatures.

Crystals of cadmium sulfate carrying the usual water of crystallization and other samples in equilibrium with the $\mathrm{D}_{2} \mathrm{O}$ content of the respective solutions were also needed to make cells of the saturated type. As a preliminary, a purified sample of cadmium sulfate was dehydrated in a muffle furnace at a temperature of $650^{\circ}$ to $700^{\circ} \mathrm{C}$. A trace of $\mathrm{SO}_{3}$ in the atmosphere was maintained throughout the process by bubbling air slowly through a tower containing fuming sulfuric acid and then through the furnace. The completeness of dehydration was tested by reheating a weighed sample. This dehydrated salt was used for saturating solutions which were employed in the cells and from which crystals were grown under controlled conditions.

To form crystals in equilibrium: with the respective solutions, a closed system consisting of two flasks connected by a glass tube was employed. The system having been evacuated, the flask containing the saturated solution was gently warmed to a few degrees above room temperature by its proximity to a small electric-light bulb, while the other flask was immersed in an ice bath. Water was slowly evaporated from the first flask and condensed in the second. The 
rate of evaporation was regulated to grow crystals of convenient size for use in the cells. By this means the necessary materials were provided without waste of the $\mathrm{D}_{2} \mathrm{O}$. Unlike the earlier cells made with small percentages of $\mathrm{D}_{2} \mathrm{O}$, no question of the exchange of the water of crystallization is involved.

Except for differences in the isotopic composition of the water, all materials used in constructing the cells were identical. Methods of purifying these materials, other than the water, have been described in an earlier publication [3].

Each sample of water was purified by distillation. Samples containing appreciable amounts of $\mathrm{D}_{2} \mathrm{O}$ were distilled slowly in a closed system under reduced pressure. Normal water was twice distilled, as we have ordinarily done in the past, the second distillation being made from a phosphoric acid solution in a special still with scrubbers and air purifiers. The conductivity of this water was $0.1 \times 10^{-6} \mathrm{ohm}^{-1}$ $\mathrm{cm}^{-1}$ at the time of distillation.

\section{CONSTRUCTION OF THE CELLS}

The details of constructing the cells were essentially those which the authors have followed in previous work. Mercurous sulfate sufficient for all cells was first washed in the customary manner. A portion of it was then made into a paste with the saturated solution of cadmium sulfate and crystals. This paste was employed in the first subgroup of cells containing normal water. The succeeding subgroups of cells containing $\mathrm{D}_{2} \mathrm{O}$ were then made in the order of increasing mole percentages. For each of these the mercurous sulfate was washed with two portions of the corresponding solution. The paste for each subgroup was made by mixing the mercurous sulfate with the saturated solution and the crystals of cadium sulfate which were in equilibrium with it. Each subgroup therefore contained paste made with cadmium sulfate solution and crystals of the same $\mathrm{D}_{2} \mathrm{O}$ content as that used in filling the cells. Throughout the work care was taken to avoid undue exposure of the $\mathrm{D}_{2} \mathrm{O}$ solutions. After all cells were completed they were hermetically sealed.

A new and improved method of introducing the amalgam into the cells was employed. This has not been described before. The hot amalgam was prepared by warming the required amounts of cadmium and mercury together in an electrically heated closed separatory funnel. The stem of the funnel was also electrically heated, and the amalgam flowed freely from the reservoir above when the stopcock was opened. This stopcock was free from lubricants of any kind. The amalgam introduced into the cells in this way was always bright and free from traces of scum which are sometimes observed under other conditions. This method of introducing the amalgam was found to be superior to the ordinary methods of ladling or the use of pipettes.

The determination of acidity of the cells, approximating $0.04 \mathrm{~N}$ acid, presented some experimental difficulties. The amount of sulfuric acid which was added was determined by weight, and in the case of cells containing normal water, the acidity was checked by direct titration. The acidities of the respective groups varied from 0.035 to $0.042 \mathrm{~N}$ acid. 


\section{DETERMINATION OF $\mathrm{D}_{2} \mathrm{O}$ CONTENT}

Although in water containing $\mathrm{D}_{2} \mathrm{O}$ and $\mathrm{H}_{2} \mathrm{O}$ there is also HDO present, throughout this paper the total amount of deuterium present has been referred to as $\mathrm{D}_{2} \mathrm{O}$ and its concentration expressed as the mole percent of $\mathrm{D}_{2} \mathrm{O}$ of the total water present.

In order to establish a relation between the electromotive force and the $\mathrm{D}_{2} \mathrm{O}$ content of the solution in the cell, it was necessary to determine the mole percentage of $\mathrm{D}_{2} \mathrm{O}$ in the water of the saturated solution. The $\mathrm{D}_{2} \mathrm{O}$ contents were found as follows: Densities of the distillates removed in forming $\mathrm{CdSO}_{4} .8 / 3\left(\mathrm{H}_{2} \mathrm{O}, \mathrm{D}_{2} \mathrm{O}\right)$ crystals in each saturated solution were determined with a 0.4 -ml picnometer. The $\mathrm{D}_{2} \mathrm{O}$ content of each distillate was then computed from the observed densities and the relation of $\mathrm{D}_{2} \mathrm{O}$ to density as given by Swift [4]. This does not, however, correspond exactly to the $\mathrm{D}_{2} \mathrm{O}$ content of the water of the saturated solutions in the cell. To find the $\mathrm{D}_{2} \mathrm{O}$ content of the saturated cadmium sulfate solution, we have assumed that the ratio of $\mathrm{D}_{2} \mathrm{O} / \mathrm{H}_{2} \mathrm{O}$ in the vapor over these solutions is the same as the ratio of $\mathrm{D}_{2} \mathrm{O} / \mathrm{H}_{2} \mathrm{O}$ in the vapor over water in which no salt is dissolved. This assumption seemed justified in order to avoid sacrificing the completed cells for a direct analysis and in view of the fact that the $\mathrm{D}_{2} \mathrm{O}$ content need be known only to 0.3 mole percent, which corresponds to a difference of 1 microvolt in the electromotive force.

In making this calculation, we have followed the procedure outlined by Smith and Wojciechowski [5] for calculating the $\mathrm{D}_{2} \mathrm{O}$ concentration in the liquid phase from the measured $\mathrm{D}_{2} \mathrm{O}$ concentration in the distillate. These values are given in table 1 .

TABLE 1.-Deuterium oxide concentration in the cells

\begin{tabular}{|c|c|c|c|}
\hline Cells & $\begin{array}{l}\text { Picnometer } \\
\text { measurement } \\
\text { of distillate }\end{array}$ & $\begin{array}{l}\text { Mole percent } \\
\text { of } \mathrm{D}_{2} \mathrm{O} \text { in } \\
\text { distillate }\end{array}$ & $\begin{array}{c}\text { Calculated } \\
\text { mole perent } \\
\text { of } \mathrm{Dg}_{2} \text { o in resi- } \\
\text { due }\end{array}$ \\
\hline 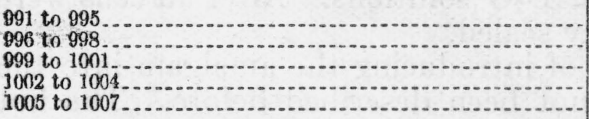 & $\begin{array}{l}\text { 1. } 00000 \\
1.00653 \\
1.05114 \\
1.08572 \\
1.10575\end{array}$ & $\begin{array}{l}0.02 \\
6.1 \\
47.4 \\
79.8 \\
98.2\end{array}$ & $\begin{array}{l}0.02 \\
6.5 \\
49.0 \\
80.6 \\
98.3\end{array}$ \\
\hline
\end{tabular}

- In Swilt's notation this is ' $d_{D_{g}}^{23} / d_{F a p}^{28} \mathbb{B g}_{\mathrm{g}} \mathrm{O}$

\section{ELECTRICAL MEASUREMENTS}

Electromotive forces of the cells were measured in terms of the group of cells which serves as the United States primary standard for the International volt. Each cell was connected in opposition to the primary reference cell, and the difference in electromotive force between the cells was measured with a special potentiometer designed by Brooks [6] for standard-cell comparisons. Instrumental errors were probably less than 0.3 microvolt.

Both the experimental cells and the primary reference cell were kept at constant temperature in oil baths controlled to $\pm 0.006^{\circ} \mathrm{C}$ or less. The primary standard is maintained at $28^{\circ} \mathrm{C}$, and the experimental cells were measured at $17^{\circ}, 20^{\circ}$, and $28^{\circ} \mathrm{C}$. 
In order to compare cells of the various subgroups, small adjustments in the values of electromotive force have been made to compensate for differences in acidity. The acidities varied from 0.035 to $0.042 N$ acid, but the electromotive forces of the new cells are reported on the uniform basis of $0.040 \mathrm{~N}$ acid. The maximum correction in any case to bring the values to this common basis did not exceed 3 microvolts.

\section{EXPERIMENTAL RESULTS}

\section{ELECTROMOTIVE FORCE OF THE CELLS}

The electromotive-force measurements at $20^{\circ}$ and $28^{\circ} \mathrm{C}$ are given in table 2. The value for each cell is the mean of five measurements at each temperature taken over a period of at least 5 days. The consistency of electromotive-force measurements is indicated by the small mean deviations of a single observation, as shown in columns 5 and 6 of the table. As in the earlier paper [1], the results are consistent in showing the effect of $\mathrm{D}_{2} \mathrm{O}$ in decreasing the electromotive force approximately in proportion to the amount present.

TABLE 2.- Electromotive forces of individual cells

\begin{tabular}{|c|c|c|c|c|c|}
\hline \multirow{2}{*}{ Cells } & \multirow{2}{*}{$\begin{array}{l}\mathrm{D}_{2} \mathrm{O} \\
\text { content }\end{array}$} & \multicolumn{2}{|c|}{$\begin{array}{l}\text { Electromotive force (average) } \\
\text { (adjusted to } 0.040 \mathrm{~N} \text { acid) }\end{array}$} & \multicolumn{2}{|c|}{$\begin{array}{l}\text { Mean deviation of } \\
\text { single observation }\end{array}$} \\
\hline & & at $20: 00^{\circ} \mathrm{C}$ & st $28.00^{\circ} \mathrm{C}$ & $20^{\circ} \mathrm{C}$ & $28^{\circ} \mathrm{C}$ \\
\hline $\begin{array}{l}991 \\
992 \\
993 \\
994 \\
995\end{array}$ & $\begin{array}{r}\text { Mole percent } \\
0.02 \\
.02 \\
.02 \\
.02 \\
.02 \\
\end{array}$ & $\begin{array}{r}\text { Int. volts } \\
1.018261_{7} \\
663 \\
66_{3} \\
67_{0} \\
663 \\
\end{array}$ & $\begin{array}{r}\text { Int. volts } \\
\text { 1. } 0178908 \\
93_{0} \\
93_{2} \\
93_{3} \\
91_{8} \\
\end{array}$ & $\begin{array}{r}\mu v \\
\pm 0.5 \\
.2 \\
.4 \\
.4 \\
.1\end{array}$ & $\begin{array}{r}\mu \theta \\
\pm 0.7 \\
.6 \\
.5 \\
.5 \\
.3\end{array}$ \\
\hline Mean & 0.02 & $1.018266_{3}$ & $1.017892_{4}$ & $\ldots$ & (n) \\
\hline 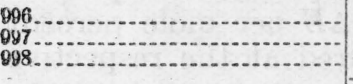 & $\begin{array}{l}6.5 \\
6.5 \\
6.5\end{array}$ & $\begin{array}{r}\text { 1. } 0182407 \\
45_{1} \\
43_{2} \\
\end{array}$ & $\begin{array}{r}1.017868_{8} \\
707 \\
69_{3} \\
\end{array}$ & $\begin{array}{r}0.5 \\
.3 \\
.4 \\
\end{array}$ & $\begin{array}{r}0.1 \\
.1 \\
.3\end{array}$ \\
\hline Mean....... & 6.5 & 1. $018243_{0}$ & $1.017869_{4}$ & -.... & ........ \\
\hline 1000 & $\begin{array}{l}49.0 \\
49.0 \\
49.0\end{array}$ & $\begin{array}{r}\text { 1. } 018091_{8} \\
88_{4} \\
91_{4}\end{array}$ & $\begin{array}{r}1.017719_{3} \\
18_{8} \\
19_{0}\end{array}$ & $\begin{array}{r}0.3 \\
.8 \\
.4\end{array}$ & $\begin{array}{r}0.5 \\
.4 \\
.3 \\
\end{array}$ \\
\hline Mean & 49.0 & $1.018090_{5}$ & $1.017719_{2}$ & -....... & - n \\
\hline $\begin{array}{l}1002 \\
1003 \\
1004\end{array}$ & $\begin{array}{l}80.6 \\
80.6 \\
80.6\end{array}$ & $\begin{array}{r}1.017961_{0} \\
638 \\
64_{8}\end{array}$ & $\begin{array}{r}1.017590_{1} \\
92_{0} \\
92_{1} \\
\end{array}$ & $\begin{array}{r}0.6 \\
.2 \\
.2 \\
\end{array}$ & $\begin{array}{r}0.3 \\
.3 \\
.2 \\
\end{array}$ \\
\hline Mean $\ldots . . . . .$. & 80.6 & $1.017963_{0}$ & $1.017591_{4}$ & (n) & (n) \\
\hline 1005 & $\begin{array}{l}98.3 \\
98.3 \\
98.3 \\
\end{array}$ & $\begin{array}{r}1.017877_{0} \\
78^{\circ} \\
78_{4} \\
\end{array}$ & $\begin{array}{r}\text { 1. } 017505_{0} \\
05_{3} \\
05_{4} \\
\end{array}$ & $\begin{array}{r}0.3 \\
.5 \\
.4 \\
\end{array}$ & $\begin{array}{r}0.6 \\
.5 \\
.3 \\
\end{array}$ \\
\hline 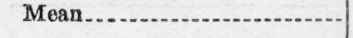 & 98.3 & 1.0178780 & 1. 0175054 & & \\
\hline
\end{tabular}

\section{RELATION OF ELECTROMOTIVE FORCE TO $\mathrm{D}_{2} \mathrm{O}$ CONTENT}

The mean electromotive force of each subgroup at $20^{\circ} \mathrm{C}$ is plotted in figure 1 with respect to the mole percent of $\mathrm{D}_{2} \mathrm{O}$ in the water of the cells. The curve is nearly linear. On the average the decrease 
in electromotive force is about 4 microvolts per mole percent of $\mathrm{D}_{2} \mathrm{O}$, but this varies from 3.6 for the lower concentrations to 5.3 at the highest concentration. The detailed results are given in table 3. For concentrations less than 50 mole percent of $\mathrm{D}_{2} \mathrm{O}$ the relationship

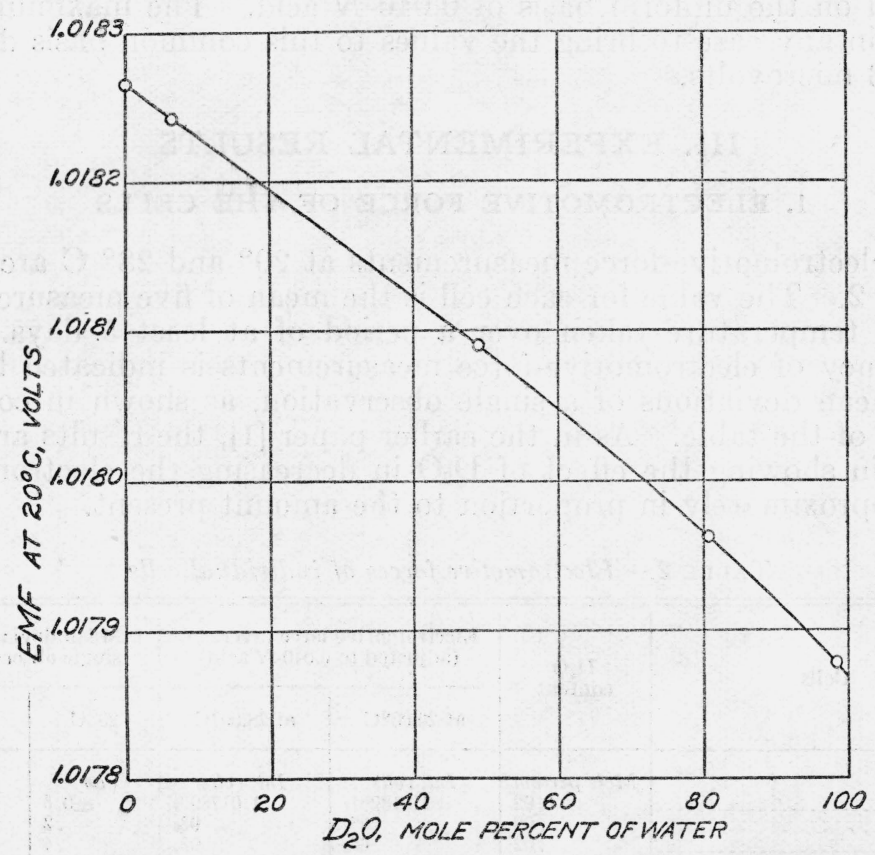

Figure 1.-Relation of electromotive force to the concentration of deuterium oxide

is linear. Above 50 percent the effect of the $\mathrm{D}_{2} \mathrm{O}$ becomes proportionately greater. In table 3 the values for $\Delta \boldsymbol{E}$ per mole percent are given as the tangents to the curve measured at the respective points.

TABLE 3.-Changes in electromotive force with $\mathrm{D}_{2} \mathrm{O}$ content

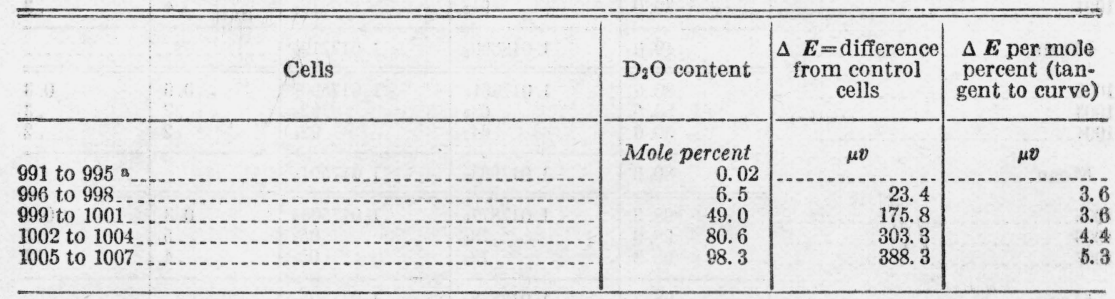

- Control cells, containing normal water.

Table 4 gives the electromotive forces for the acid cells used in these experiments, at even percentages of $\mathrm{D}_{2} \mathrm{O}$. These values were read from the curve in figure 1. Estimated values for the Weston normal (neutral) cell are also included for corresponding percentages of $\mathrm{D}_{2} \mathrm{O}$. 
TABLE 4.-Effect of $\mathrm{D}_{2} \mathrm{O}$ on the electromotive force of the Weston normal cell

\begin{tabular}{|c|c|c|c|}
\hline Percentage of $\mathrm{D}_{2} \mathrm{O}$ in the water & $\begin{array}{l}\text { Observed de- } \\
\text { crease in elec- } \\
\text { tromotive force }\end{array}$ & $\begin{array}{c}\text { Electromotive } \\
\text { force of cell at } \\
20^{\circ} \mathrm{C}(0.04 N \\
\text { acid) }\end{array}$ & $\begin{array}{l}\text { Estimated elec- } \\
\text { tromotive force } \\
\text { of Weston nor- } \\
\text { mal cell }\end{array}$ \\
\hline $\begin{array}{l}10 \\
100 \\
60 \\
60\end{array} 0^{0}$ & $\begin{array}{r}\mu \nu \\
36 \\
72 \\
108 \\
144 \\
180 \\
219 \\
259 \\
302 \\
348 \\
399\end{array}$ & $\begin{array}{r}\text { Int. volts } \\
1.018267 \\
8231 \\
8195 \\
8159 \\
8123 \\
8087 \\
8048 \\
8008 \\
7965 \\
7919 \\
7868\end{array}$ & $\begin{array}{r}\text { Int. volts } \\
\text { o. } 018300 \\
8264 \\
8228 \\
8192 \\
8156 \\
8120 \\
8081 \\
8041 \\
7998 \\
7952 \\
7901\end{array}$ \\
\hline
\end{tabular}

- The Weston normal cell has an electromotive force at $20^{\circ} \mathrm{C}$ of 1.018300 Int. volts by definition.

\section{TEMPERATURE COEFFICIENT AND HYSTERESIS}

Measurements of electromotive force were made at $17^{\circ}, 20^{\circ}$, and $28^{\circ} \mathrm{C}$ for the purpose of determining how nearly the temperature coefficient of these cells agrees with the generally accepted value based on the International temperature formula [7]. Observed differences in electromotive force at these temperatures are given in table 5 . The differences in electromotive force are based on values observed after ample time had been allowed for the cells to reach equilibrium at each temperature.

It is evident from these data that the temperature coefficient is practically independent of the $\mathrm{D}_{2} \mathrm{O}$ content. Observed differences are in better agreement with the formula of Vigoureux and Watts [8] than with the International formula.

The authors have found by experience with other groups of acid cells that the observed difference, $\boldsymbol{E}_{20}-\boldsymbol{E}_{28}$, is substantially in agreement with the present experimental results, that is, less than the value which would be calculated from the International formula.

TABLE 5.-Change in electromotive force with temperature, and hysteresis measurements

\begin{tabular}{|c|c|c|c|c|c|}
\hline \multirow{2}{*}{ Cells } & \multirow{2}{*}{$\mathrm{D}_{2} \mathrm{O}$ content } & \multicolumn{2}{|c|}{ Vaiues of $\Delta \boldsymbol{E} / \Delta \boldsymbol{t}$} & \multicolumn{2}{|c|}{ Hysteresis effect } \\
\hline & & $17^{\circ}$ to $20^{\circ} \mathrm{C}$ & $20^{\circ}$ to $28^{\circ} \mathrm{C}$ & $20^{\circ}$ to $28^{\circ} \mathrm{C}$ & $28^{\circ}$ to $20^{\circ} \mathrm{C}$ \\
\hline $\begin{array}{l}991 \text { to } 995 \\
996 \text { to } 998 \text { to } 1001 \\
1002 \text { to } 1004 \\
1005 \text { to } 1007\end{array}$ & $\begin{array}{r}\text { Mole percent } \\
0.02 \\
6.5 \\
49.0 \\
80.6 \\
88.3 \\
\end{array}$ & 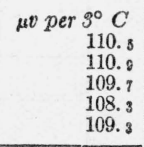 & 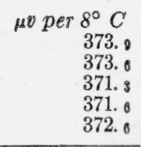 & $\mu v \begin{array}{l}-2 \\
-1 \\
-3 \\
-2 \\
-1\end{array}$ & A) $\begin{array}{r}-25 \\
-35 \\
-17 \\
-5 \\
-6\end{array}$ \\
\hline $\begin{array}{l}\text { By International formula } \\
\text { By formula of Vigoureux and } \\
\text { Watts........ }\end{array}$ & -- & $\begin{array}{l}113.0 \\
109.8\end{array}$ & $\begin{array}{l}380.5 \\
370.1\end{array}$ & & -- \\
\hline
\end{tabular}

- Electromotive forces observed 2 to 3 hours after temperature change minus equilibrium electromotive force at new temperature.

When changing the temperature of the cells from $20^{\circ}$ to $28^{\circ} \mathrm{C}$ and back to $20^{\circ} \mathrm{C}$, they were removed from one oil bath and plunged into another at a different temperature. These sudden temperature changes would be reflected in abnormal electromotive forces if the cells were subject to hysteresis. Two to three hours were allowed for 
thermal equilibrium to be established, and the electromotive forces were then read and recorded for comparison with equilibrium values obtained later. The differences, which may be taken as a measure of the hysteresis effect, are given in table 5 . It is apparent that hysteresis of all the cells was less when an increase in temperature occurred than when the temperature was decreased by the same amount. This is in line with common experience. The most noteworthy feature of the measurements is to show that hysteresis is less in the cells having the higher concentrations of $\mathrm{D}_{2} \mathrm{O}$, but some irregularities may have been caused by variations of the size of crystals in cells of the various subgroups.

\section{INTERNAL RESISTANCE}

The internal resistance of standard cells is a useful criterion of their condition. Generally the internal resistance increases somewhat with age. If this occurs in unsaturated cells, the increase in resistance is usually an indication that a gas bubble has formed between the surface of the amalgam and the diaphragm. In saturated cells, the increase in resistance may be the result of (1) coalescing of the crystals of cadmium sulfate, (2) the formation of small crystals which tend to fill the interstices between larger crystals, and (3) the formation of gas. Cells of the usual type illustrated in a paper by the present authors [9] have an initial resistance of 500 to $700 \mathrm{ohms}$ at $28^{\circ} \mathrm{C}$. The exact value of resistance in this range is not a matter of importance, and it varies considerably with small differences in dimensions and other details of construction. If the resistance increases to $1,200 \mathrm{ohms}$ or more, the cells are likely to be unreliable.

TABLE 6.-Resistance of cells at $20^{\circ}$ and $28^{\circ} \mathrm{C}$

\begin{tabular}{|c|c|c|c|c|}
\hline \multirow{2}{*}{ Cells } & \multirow{2}{*}{$\mathrm{D}_{2} \mathrm{O}$ content } & \multicolumn{2}{|c|}{ Resistance at- } & \multirow[b]{2}{*}{ Ratio $R_{30} / R_{28}$} \\
\hline & & $20.00^{\circ} \mathrm{C}$ & $28.00^{\circ} \mathrm{C}$ & \\
\hline $\begin{array}{l}991 \\
992 \\
994\end{array} 93$ & $\begin{array}{r}\text { Mole percent } \\
0.02 \\
.02 \\
.02 \\
.02 \\
.02\end{array}$ & $\begin{array}{r}\text { Ohms } \\
962 \\
701 \\
656 \\
827 \\
754\end{array}$ & $\begin{array}{r}\text { Ohms } \\
706 \\
567 \\
524 \\
649 \\
610\end{array}$ & $\begin{array}{l}1.36 \\
1.24 \\
1.25 \\
1.27 \\
1.24\end{array}$ \\
\hline Mean. . & 0.02 & 780 & 611 & 1.27 \\
\hline 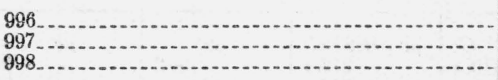 & $\begin{array}{l}6.5 \\
6.5 \\
6.5\end{array}$ & $\begin{array}{l}905 \\
707 \\
707\end{array}$ & $\begin{array}{l}731 \\
554 \\
563\end{array}$ & $\begin{array}{l}1.24 \\
1.28 \\
1.26\end{array}$ \\
\hline Mean.. & 6.5 & 773 & 616 & 1.26 \\
\hline $\begin{array}{l}999 \\
1000 \\
1001\end{array}$ & $\begin{array}{l}49.0 \\
49.0 \\
49.0\end{array}$ & $\begin{array}{r}732 \\
1,041 \\
754\end{array}$ & $\begin{array}{l}589 \\
753 \\
597\end{array}$ & $\begin{array}{l}1.24 \\
1.38 \\
1.26\end{array}$ \\
\hline Mean... & 49.0 & 842 & 648 & 1.29 \\
\hline 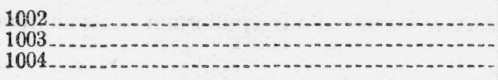 & $\begin{array}{l}80.6 \\
80.6 \\
80.6\end{array}$ & $\begin{array}{l}881 \\
823 \\
971\end{array}$ & $\begin{array}{l}690 \\
642 \\
720\end{array}$ & $\begin{array}{l}1.28 \\
1.28 \\
1.35\end{array}$ \\
\hline Mean & 80.6 & 892 & 682 & 1.30 \\
\hline $1005-1006$ & $\begin{array}{l}98.3 \\
98.3 \\
98.3 \\
\end{array}$ & $\begin{array}{r}1,053 \\
834 \\
779 \\
\end{array}$ & $\begin{array}{l}788 \\
667 \\
608 \\
\end{array}$ & $\begin{array}{l}1.34 \\
1.25 \\
1.28\end{array}$ \\
\hline Mean & 98.3 & 889 & 688 & 1.29 \\
\hline
\end{tabular}


Interest in the internal resistances of the cells containing $\mathrm{D}_{2} \mathrm{O}$ relates primarily to the effect of substituting deuterium oxide for normal water. Notwithstanding the irregularities of the individual values reported in table 6 , the average measurements made at $20^{\circ}$ and $28^{\circ} \mathrm{C}$ are concordant in showing a slight increase in resistance with increasing $\mathrm{D}_{2} \mathrm{O}$ content. The average difference between cells containing 98 mole percent $\mathrm{D}_{2} \mathrm{O}$ and those with ordinary water is 13 percent. The ratio of resistances for the respective cells at $20^{\circ}$ and $28^{\circ} \mathrm{C}$ is, however, approximately constant irrespective of the $\mathrm{D}_{2} \mathrm{O}$ content. This ratio, which averages 1.28 for the present group of cells, agrees substantially with the value 1.24 obtained in the earlier work [1], to which reference should be made for the method of making the measurements.

\section{CONSTANCY OF ELECTROMOTIVE FORCE}

Periodic measurements of the cells numbered 991 to 1007 have been made during the past 18 months. In addition, similar measurements on the earlier group, Nos. 956 to 967 , during a period of 4 years are available. These measurements are summarized in table 7. In general the electromotive forces of cells in the later group, containing the higher percentages of $\mathrm{D}_{2} \mathrm{O}$, have been more constant than in the case of the earlier group, but the same is also true of the respective control experiments, which included cells without the addition of deuterium oxide.

TABLE 7.-Constancy of electromotive force of cells containing $\mathrm{D}_{2} \mathrm{O}$

\begin{tabular}{|c|c|c|c|c|c|c|}
\hline \multirow{2}{*}{ Cells } & \multirow{2}{*}{$\mathrm{D}_{2} \mathrm{O}$ content } & \multirow{2}{*}{$\begin{array}{l}\text { Electromo- } \\
\text { tive force, } \\
20^{\circ} \mathrm{C} \text { at } 6 \\
\text { months }\end{array}$} & \multicolumn{4}{|c|}{ Subsequent changes in electromotivo force at- } \\
\hline & & & 12 months & 18 months & 30 months & 48 months \\
\hline $\begin{array}{l}956 \text { to } 958 \\
959 \text { to } 961 \\
962 \text { to } 964 \text { to } 967\end{array}$ & $\begin{array}{r}\text { Mole percent } \\
0.02 \\
.76 \\
2.27 \\
4.98\end{array}$ & \begin{tabular}{r}
\multicolumn{1}{l}{0} \\
$-18273_{0}$ \\
$8270_{0}$ \\
$8267_{0}$ \\
$8258_{5}$
\end{tabular} & $\mu v \begin{array}{r} \\
+1.8 \\
+2.0 \\
+1.8 \\
+1.8\end{array}$ & $\begin{array}{l}\mu \\
+3.0 \\
+3.5 \\
+3.0 \\
+3.8\end{array}$ & $\begin{array}{l}\mu v \\
+6.0 \\
+6.5 \\
+6.0 \\
+6.5\end{array}$ & 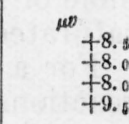 \\
\hline $\begin{array}{l}991 \text { to } 995 \\
996 \text { to } 998 \\
999 \text { to } 1001 \\
1002 \text { to } 1004 \\
1005 \text { to } 1007\end{array}$ & $\begin{array}{l}0.02 \\
6.5 \\
49.0 \\
80.6 \\
98.3\end{array}$ & $\begin{array}{r}\text { b1. } 018267 \mathrm{~s} \\
8242_{\mathrm{s}} \\
8090_{\mathrm{s}} \\
7963_{0} \\
7877_{\mathrm{s}}\end{array}$ & $\begin{array}{r}+1.0 \\
+0.5 \\
+0.5 \\
0.0 \\
0.0\end{array}$ & $\begin{array}{r}+1.8 \\
+1.0 \\
+1.0 \\
0.0 \\
0.0\end{array}$ & 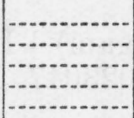 & 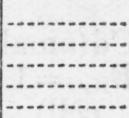 \\
\hline
\end{tabular}

- All cells of the group 956 to 967 were $0.03 \mathrm{~N}$ acid. To correct the electromotive-force values to the same basis as for cells 991 to 1007 , subtract 6 microvolts.

b The electromotive forces of all cells of the group 991 to 1007 are adjusted to $0.04 \mathrm{~N}$ acid.

The electromotive force of the earlier cells has increased uniformly during 4 years at a rate of about 2 microvolts per year. It is anticipated that this rate of change will eventually decrease. Several reasons might be assigned for this increase in electromotive force, such as the effect of the glass container in neutralizing part of the acid within the cells. The most significant fact seems to be the uniform behavior of the various subgroups, which have maintained their relative electromotive forces during 4 years.

The later group of cells containing the higher percentages of $\mathrm{D}_{2} \mathrm{O}$ have been remarkably constant over a period of 18 months. This was true also of the control cells, Nos. 991 to 995 . The electromotive force of these cells is 1.5 microvolts higher now than 1 year previously, but the two groups containing the highest percentages of $\mathrm{D}_{2} \mathrm{O}, 80$ 
percent in cells 1002 to 1004 , and 98 percent in cells 1005 to 1007 , have the same respective electromotive forces to within 0.5 microvolt as they had 12 months previously. Whether this result can be attributed wholly to the use of $\mathrm{D}_{2} \mathrm{O}$ is not entirely certain. The fact remains, however, that these cells in an early period of their life are as constant as the much larger group of seasoned cells which constitute the Bureau's primary reference standard.

All of the cells made with $\mathrm{D}_{2} \mathrm{O}$ have been examined for the formation of gas which sometimes occurs in acid cells, but no significant amount was found in any of them.

In general the results obtained with the later group seem to justify the conclusion given in the earlier paper [1] that cells containing $\mathrm{D}_{2} \mathrm{O}$ are fully as reproducible and constant as cells made with normal water.

\section{RELATIVE FREE ENERGY OF $\mathrm{CdSO}_{4}$ IN $\mathrm{H}_{2} \mathrm{O}$ AND $\mathrm{D}_{2} \mathrm{O}$ SOLUTIONS}

Some interesting properties of the cell constituents can be gotten from the thermodynamical comparison of the $\mathrm{H}_{2} \mathrm{O}$ and $\mathrm{D}_{2} \mathrm{O}$ cells. One can determine the difference in the partial molal free energy of the cadmium sulfate in $\mathrm{D}_{2} \mathrm{O}$ saturated with respect to $\mathrm{CdSO}_{4}$. $8 / 3 \mathrm{D}_{2} \mathrm{O}$ and in an $\mathrm{H}_{2} \mathrm{O}$ solution of the same mole fraction of $\mathrm{CdSO}_{4}$. At $20^{\circ} \mathrm{C}$ a saturated solution contains 0.0602 mole of $\mathrm{CdSO}_{4}$ per mole of $\mathrm{D}_{2} \mathrm{O}$. The electromotive force of the saturated $\mathrm{D}_{2} \mathrm{O}$ cell is 1.017868 Int. volts (fig. 1). Since $\mathrm{CdSO}_{4}$ is less soluble in $\mathrm{D}_{2} \mathrm{O}$ than in $\mathrm{H}_{2} \mathrm{O}$, an $\mathrm{H}_{2} \mathrm{O}$ solution of the same mole fraction is unsaturated at $20^{\circ} \mathrm{C}$. From measurements of the relation of electromotive force to $\mathrm{CdSO}_{4}$ composition in cells containing $\mathrm{H}_{2} \mathrm{O}$ [10], one calculates the electromotive force of a cell containing 0.0602 mole $\mathrm{CdSO}_{4}$ per mole of $\mathrm{H}_{2} \mathrm{O}$ to be 0.00478 volt higher than a cell containing an $\mathrm{H}_{2} \mathrm{O}$ saturated solution at $20^{\circ} \mathrm{C}$.

For a consideration of the partial molal free energy changes, the reactions for the cells may be written in the condensed form.

$\mathrm{Cd}$ (amalgam) $+\mathrm{Hg}_{2} \mathrm{SO}_{4}=\mathrm{CdSO}_{4}\left(0.0602\right.$ mole per mole $\left.\mathrm{H}_{2} \mathrm{O}\right)+2 \mathrm{Hg}$ (1)

$\boldsymbol{E}_{\mathrm{H}_{3} \mathrm{O}}=1.023047$ Int. volts (calculated from emf of saturated $\mathrm{H}_{2} \mathrm{O}$ cell).

$\mathrm{Cd}$ (amalgam) $+\mathrm{Hg}_{2} \mathrm{SO}_{4}=\mathrm{CdSO}_{4}\left(0.0602\right.$ mole per mole $\left.\mathrm{D}_{2} \mathrm{O}\right)+2 \mathrm{Hg}(2)$ $\boldsymbol{E}_{\mathrm{D}_{2} \mathrm{O}}=1.017868$ Int. volts (observed value)

If eq 2 is subtracted from eq 1 , eq 3 is

$\mathrm{CdSO}_{4}\left(0.0602\right.$ mole per mole $\left.\mathrm{D}_{2} \mathrm{O}\right)=\mathrm{CdSO}_{4}\left(0.0602\right.$ mole per mole $\left.\mathrm{H}_{2} \mathrm{O}\right)$

$$
\Delta F_{3}=\Delta F_{\mathrm{H}_{2} \mathrm{O}}-\Delta F_{\mathrm{D}_{2} \mathrm{O}}=\left[\left(\bar{F}_{\mathrm{CdSO}_{4}}\right)_{\mathrm{H}_{3} \mathrm{O}}-\left(\bar{F}_{\mathrm{CdSO}_{4}}\right)_{\mathrm{D}_{2} \mathrm{O}}\right]_{\substack{0.0602 \text { mole CasO } \\ \text { per mole water }}}
$$

$$
\begin{aligned}
& =-2 \times \boldsymbol{F}\left(\boldsymbol{E}_{\mathrm{H}_{2} \mathrm{O}}-\boldsymbol{E}_{\mathrm{D}_{2} \mathrm{O}}\right) \\
& =-2 \times 96500 \times 0.005179 \\
& =-1,000 \pm 20 \text { Int. joules mole }
\end{aligned}
$$

The partial molal free energy of $\mathrm{CdSO}_{4}, \bar{F}_{\mathrm{CaS} \cap_{4}}$, is $1,000 \pm 20$ Int. joules greater in $\mathrm{D}_{2} \mathrm{O}$ than in $\mathrm{H}_{2} \mathrm{O}$ solutions whose concentration is 
0.0602 mole $\mathrm{CdSO}_{4}$ per mole of water at $20^{\circ} \mathrm{C}$. From the constancy of the difference between the electromotive force of the saturated $\mathrm{H}_{2} \mathrm{O}$ and $\mathrm{D}_{2} \mathrm{O}$ cells and the small variation in concentration of the saturated $\mathrm{CdSO}_{4}$ solutions over the range $17^{\circ}$ to $28^{\circ} \mathrm{C}$, the value calculated for the difference in partial molal free energy of $\mathrm{CdSO}_{4}$ in $\mathrm{H}_{2} \mathrm{O}$ and $\mathrm{D}_{2} \mathrm{O}$ solutions is independent of temperature to within the limits of error of this calculation.

Since the cells on which these measurements were made contained a small amount of added $\mathrm{H}_{2} \mathrm{SO}_{4}$, this discussion strictly applies only to solutions which are 0.032 normal in $\mathrm{H}_{2} \mathrm{SO}_{4}$ and saturated with respect to $\mathrm{Hg}_{2} \mathrm{SO}_{4}\left(5.2 \times 10^{-5}\right.$ mole $\mathrm{Hg}_{2} \mathrm{SO}_{4}$ per mole of water [11]).

\section{CONCLUSION}

The substitution of $\mathrm{D}_{2} \mathrm{O}$ for normal water in saturated standard cells affords a variation in the customary type of cell which appears to be equally as good as the best Weston normal cells, now used as a standard for the International volt. More experience with deuterium cells is doubtless required, but at the present time cells containing high percentages of $\mathrm{D}_{2} \mathrm{O}$ seem to offer the best possibility of obtaining another type of cell which can be used as a primary standard. If several groups of different types of cells maintain the same relative values of electromotive force over long periods of time, the evidence that each group is constant is improved. The Bureau now depends on groups of acid and neutral Weston cells and hopes ultimately to employ the deuterium cells as a part of the standard.

\section{REFERENCES}

[1] L. H. Brickwedde and G. W. Vinal, J. Research NBS 20, 599 (1938) RP1094.

[2] G. W. Vinal and L. H. Brickwedde, J. Research NBS $\mathbf{2 6 , 4 5 5}$ (1941) RP1389.

[3] G. W. Vinal, D. N. Craig, and L. H. Brickwedde, Trans. Electrochem. Soc. $58,146(1935)$.

[4] E. Swift, Jr., J. Am. Chem. Soc. 61, 198 (1939).

[5] E. R. Smith and M. Wojciechowski, J. Research NBS 17, 841 (1936) RP947.

[6] H. B. Brooks, BS J. Research 11, 211 (1933) RP586.

[7] Report of London Conference on Electrical Units and Standards, Schedule C (1908).

[8] P. Vigoureux and S. Watts, Proc. Phys. Soc. (London) 45, 172 (1933).

[9] G. W. Vinal and M. L. Howard, BS J. Research 11, 255 (1933) RP588.

[10] W. C. Vosburgh and M. Eppley, J. Am. Chem. Soc. 45, 2268 (1923).

[11] F. E. Smith, Glazebrook's Dictionary of Applied Physics 2, 267 (The Macmillan Co., 60 Fifth Avenue, New York, N. Y., 1922).

Washington, September 16, 1941. 